\title{
The Political Philosophy of Henry Sidgwick
}

David Miller

Nuffield College, University of Oxford

Corresponding author. Email david.miller@nuffield.ox.ac.uk

\section{Abstract}

Why has Sidgwick's political philosophy fallen into oblivion while his ethics continues to be celebrated? Not because his performance in that field was inferior, nor because his choice of topics has become outdated, nor because his conclusions were largely conservative. Instead the problem stems from the weight he attached to common sentiments and beliefs in his application of the utility principle, illustrated by his treatment of topics such as secession and colonialism. Moreover his Elements of Politics is arranged in such a way that he never has to confront the basic question of what makes states legitimate. This means that neither political moralists, who want to see the utility principle applied in more radical fashion, nor political realists, for whom the problem of establishing political order is central, find much to commend in his political philosophy.

\section{Introduction}

Why has Henry Sidgwick's political philosophy disappeared from view, to the extent that it barely registers in the in the history of the subject? This is the question I shall address here. That it has indeed almost entirely disappeared from view is easy to demonstrate. There are no chapters on (or often even mentions of) Sidgwick in any of the Plato-to-Nato style surveys that I have consulted. ${ }^{1}$

\footnotetext{
${ }^{1}$ Such as, for example, Political Thinkers: From Socrates to the Present, ed. by David Boucher and Paul Kelly (Oxford: Oxford University Press, 2003); Alan Ryan, On Politics: A History of Political Thought from Herodotus to the Present (London: Allen Lane, 2012); George Klosko, The History of Political Theory: An Introduction, 2 vols (Oxford: Oxford University Press, 2012-13); Bruce Haddock, A
} 
But even in more specialised works, he hardly appears. For example, the Cambridge History of Nineteenth Century Political Thought, which runs to well over 1000 pages, contains just five passing references to Sidgwick, in three of which he is simply listed along with other authors. In the Oxford Handbook of the History of Political Philosophy, $800+$ pages, he goes one better, six mentions, but all of these are connected to his role as a methodological precursor of Rawls, specifically as someone whose work anticipated the Rawlsian device of reflective equilibrium.

What can explain this neglect of Sidgwick as a political philosopher? He did after all write four equally substantial books, of which one was on ethics, one on political economy and two on politics. ${ }^{2}$ As far as we can tell, he regarded each of these, perhaps with the exception of the last, The Development of European Polity, as equally important. ${ }^{3}$ But how differently they have been received, from their first publication up until now! $!^{4}$ The Methods of Ethics is routinely praised as one

History of Political Thought: From Antiquity to the Present (Cambridge: Polity, 2008). Nor does he make an appearance in surveys that begin later, such as lain Hampsher-Monk, A History of Modern Political Thought: Major Political Thinkers from Hobbes to Marx (Oxford: Blackwell, 1992) or Murray Forsyth and Maurice Keens-Soper, The Political Classics: Green to Dworkin (Oxford: Oxford University Press, 1996).

${ }^{2}$ I am setting aside here his Outlines of the History of Ethics for English Readers, published in 1886, since this is a largely expository work, as well as the various collections of lectures that were published posthumously - as indeed was The Development of European Polity, though Sidgwick had intended to publish this in book form to complement The Elements of Politics.

${ }^{3}$ Or unimportant: Sidgwick was inclined to doubt the success of any of his books. But we should probably set this aside as characteristic self-deprecation. 
of the two or three best books on ethics ever written: see, for example, the Preface to On What Matters, where Parfit describes it as 'the book it would be best for everyone interested in ethics to read, remember, and be able to assume that others have read'. ${ }^{5}$ In contrast, both The Principles of Political Economy and The Elements of Politics have been gathering dust on library shelves, and probably few philosophers today are even aware of their existence. ${ }^{6}$ Rawls, for example, who

\footnotetext{
${ }^{4}$ It has been claimed that Sidgwick's contribution to ethics also fell into neglect until revived in the second half of the twentieth century via the work of Rawls, Singer and others. However the evidence does not bear this out. Sidgwick's high standing among his immediate philosophical successors is discussed in Bart Schultz, Henry Sidgwick: Eye of the Universe (Cambridge: Cambridge University Press, 2004), ch. 1. In the first half of the following century his work was discussed by, among others, Broad, Prichard, Rashdall and Ross, and Rawls himself cites Sidgwick as early as 1955 in his paper 'Two Concepts of Rules'. See also here Anthony Skelton, On Sidgwick's Demise: a Reply to Professor Deigh, Utilitas 22 (2010), 70-77, replying to John Deigh, Sidgwick's Epistemology, Utilitas 19 (2007), 435-46.
}

${ }^{5}$ Derek Parfit, On What Matters (Oxford: Oxford University Press, 2010), Vol. 1, p. xl. For similar encomia, see C.D. Broad, Five Types of Ethical Theory (London: Kegan Paul, 1930), p. 143 and Roger Crisp, The Cosmos of Duty: Henry Sidgwick's Methods of Ethics (Oxford: Oxford University Press, 2015), pp. vii-x.

\footnotetext{
${ }^{6}$ The Elements of Politics seems to have attracted little attention outside of Cambridge itself from the moment of its publication. For example, Ernest Barker's survey Political Thought in England from Herbert Spencer to the Present Day, published in 1915, contains not a single mention of
} Sidgwick's book. In the early $20^{\text {th }}$ century, it was dismissed as outmoded by critics such as Graham 
praised The Methods of Ethics as 'the first truly academic work in moral philosophy (in English), modern both in its method and in the spirit of its approach', ${ }^{7}$ and regularly taught Sidgwick in his course on the history of political philosophy, appears to have completely overlooked Sidgwick's political writings. Instead, in his lectures on Sidgwick, now available in book form, ${ }^{8}$ he relies entirely on the Methods, and treats Sidgwick simply as the exponent of a utilitarian theory of distributive justice. No other source is mentioned and no other topic touched upon.

What can explain this dramatic divergence between Sidgwick's reputation as a moral philosopher and as a political philosopher? Let me explore some possible answers. Is Sidgwick's work in political philosophy simply inferior in quality to his work in moral philosophy? There is no evidence at all to support this suggestion. The particular qualities that make Sidgwick's approach to ethics so distinctive - his close interrogation of the moral opinions of thoughtful persons, with different sides of each case carefully considered and counter-examples introduced, leading to perplexities that common sense alone cannot resolve without appeal to general utility - are equally on display in his political writing, alongside a comprehensive knowledge of the history and workings of political institutions. Of course, some people have found Sidgwick's forensic technique boring: there is too much even-handedness, too much willingness to explore possible counter-arguments, too little by way of firm conclusion. Parfit refers to this in his Preface, but argues that people who react in this way are missing one of Sidgwick's chief philosophical merits, his ability to see objections to his own

Wallas and Harold Laski: see Stefan Collini, Donald Winch and John Burrow, That Noble Science of Politics (Cambridge: Cambridge University Press, 1983), Epilogue.

\footnotetext{
${ }^{7}$ John Rawls, Lectures on the History of Political Philosophy, ed. by Samuel Freeman (Cambridge, MA: Harvard University Press, 2007), p. 378.
}

${ }^{8}$ Rawls, Lectures on the History of Political Philosophy, pp. 375-415. 
views. Whichever view you take, you will find your reaction to Methods mirrored in your reaction to Elements. ${ }^{9}$ In terms of style and approach there is nothing to separate them.

As an alternative explanation, has Sidgwick's political philosophy perhaps become outdated in the way that his moral philosophy hasn't? After all the agenda of politics - the questions that people find worth discussing - does change more rapidly that the agenda of ethics. But that suggestion doesn't hold water either. It's true that Sidgwick discusses topics, such as whether contracts should be defined so as to allow payment in either gold or silver coin, or whether the government should pay teachers of morality, that we might think of as antiquated. But overall the Elements is impressive for the sheer breadth of its subject matter, covering not only domestic policies and institutions, but also questions of territory, immigration, colonisation, international law, justice in war - questions hardly broached by most of his contemporaries, but plainly of great relevance both then and now. He has much to say as well about the morality of a market economy, about the sources of economic inequality and what might be done to mitigate it, and about the role of the state in supplying public goods, that speaks directly to us today. The problem with Sidgwick's political philosophy, if there is one, is certainly not its practical irrelevance.

Another diagnosis attributes the problem to the moderately conservative conclusions Sidgwick tends to draw from his analysis. That seems to have been the verdict of his early reviewers, who complained that what appeared at first sight to be an abstract discussion of political principles

\footnotetext{
${ }^{9}$ For a (partially) dissenting view, see Stefan Collini, My Roles and their Duties: Sidgwick as Philosopher, Professor and Public Moralist, in Henry Sidgwick, ed. by Ross Harrison (Oxford: Oxford University Press, 2001), pp. 9-49, at p. 44. Collini finds the 'sustained architectonic command' displayed in The Methods of Ethics missing in Sidgwick's later books.
} 
actually turned out to be a higher level description of existing political practice. ${ }^{10}$ One wrote that 'when he tries to derive institutions from his fundamental principles, he is really conforming the principles to the institutions'. ${ }^{11}$ According to another, 'Professor Sidgwick argues deductively from "psychological propositions not universally and absolutely true, but approximately true of civilised men," and yet, somehow, the conclusion again and again turns out to be just what we have in the present British constitution'. ${ }^{12}$ But if this were a sufficient reason for dismissing Sidgwick, it would imply that there cannot be such a thing as a conservative political philosophy worth taking seriously. More or less the same charge of using abstract philosophical arguments to arrive at a political destination very close to the prevailing political arrangements could be laid at the door of Hegel's Philosophy of Right, for example, and yet Hegel's reputation as a political philosopher of the first rank goes unchallenged.

So what exactly is the problem with Sidgwick qua political philosopher? It is not, I have suggested, with the quality of his writing about politics; it is not because he chose the wrong topics to write about; nor is it because he reached largely conservative conclusions (though as we shall see later it may have something to do with the way in which he reached them). Admittedly he held views on number of topics - race, colonialism, women in politics - that we now find unpalatable. But if that

${ }^{10}$ Alongside the two reviews referred to below, The Elements of Politics received lukewarm notices from Hastings Rashdall in The Economic Review, 2 (1892), 275-78 and Woodrow Wilson in The Dial, 12 (1891), 215-16. My concern here, however, is not with the book's immediate reception but with the reasons for its long-term neglect.

${ }^{11}$ William A. Dunning in Political Science Quarterly, 7 (1892), p. 537.

${ }^{12}$ David G. Ritchie in International Journal of Ethics, 2 (1981-2), p. 255. 
disqualifies him, it must also disqualify almost all political philosophers of past centuries, and yet we continue to read and learn from them. So what else is it?

\section{Questions of Method}

We need to begin with Sidgwick's distinctive methodology. He sees ethics and political philosophy as two closely connected branches of practical reason, and indeed takes some pains in the second chapter of Methods to explain their relationship: 'Ethics aims at determining what ought to be done by individuals, while Politics aims at determining what the government of a state or political society ought to do and how it ought to be constituted. ${ }^{13}$ And in both cases the approach taken is to start with common opinion - or more strictly the opinions shared by civilised and reflective people - and then to see how far they can be rationalised in their own terms, or how far, by contrast, they can only be made clear and consistent by being incorporated, with some modifications, into a utilitarian framework. As he puts it at the very beginning of Elements:

The primary aim of the Political Theory that is here to be expounded is not to supply any entirely new method of obtaining reasoned answers to political questions; but rather, by careful reflection, to introduce greater clearness and consistency into the kind of thought and reasoning with which we are all more or less familiar. ${ }^{14}$

From this point of view, the main difference between the two works is that whereas in Methods Sidgwick aims to defend utilitarianism by showing that it alone can render intuitionist ethics

\footnotetext{
${ }^{13}$ Henry Sidgwick, The Methods of Ethics, $7^{\text {th }}$ ed. (London: Macmillan, 1907), p. 15 (hereinafter Methods).
}

${ }^{14}$ Henry Sidgwick, The Elements of Politics, $2^{\text {nd }}$ ed. (London: Macmillan, 1897), p. 1. (hereinafter Elements). 
coherent, in Elements he offers no such explicit defence, but rather takes utility for granted as the relevant external standard by which to attempt to rationalise popular thought. He says, rather casually, that he assumes 'the majority of my readers' will take 'the general happiness' to be the ultimate end to which political efforts should be directed. ${ }^{15}$ But now the question arises as to how this standard is to be applied in practical reasoning. Readers of Methods will be familiar with the passages in which Sidgwick agonises over the problem of how far a utilitarian should wish other people self-consciously to follow the principle of utility when deciding how to act, rather than to observe the rules of customary morality, imperfectly utilitarian in effect though these are. ${ }^{16}$ In the political sphere a parallel problem may arise in the case of institutions that are well established, but less than ideal by utilitarian standards. Early on in Elements Sidgwick gives the example of trial by jury, which he assumes to be a very imperfect vehicle for the delivery of criminal justice. But, he says, in a country where confidence in the institution has been built up over centuries, this defect may be more than compensated for - presumably on the grounds, though he doesn't spell this out, that belief in the virtues of jury trial makes people more willing to serve on juries and to accept the verdicts that they reach. ${ }^{17}$ So, if people strongly believe in institution $\mathrm{X}$, and are accordingly willing to comply with it, this provides utilitarian grounds for preferring $\mathrm{X}$ to $\mathrm{Y}$, even though $\mathrm{Y}$, once established, would do a better job of providing the service that X now provides. Sidgwick has already allowed the application of his utility principle to be steered by the force of popular opinion

${ }^{15}$ Elements, p. 7.

${ }^{16}$ Methods, Book IV, ch. 5.

${ }^{17}$ Elements, p. 14. 
even when the content of popular opinion is such that on utilitarian grounds one would prefer it to be different.

Readers of Methods will also be familiar with the 'dualism of practical reason' that left Sidgwick unable to demonstrate the rational superiority of utilitarianism to ethical egoism. Although the Elements assumes that this dualism has already been overcome in favour of the former, it introduces a second one: the conflict between national and cosmopolitan ideals of political organization. On the first of these views, the state's purpose is to promote the general happiness of its own citizens; on the second, it is to promote the happiness of all the human beings affected by its actions. Now when he confronts this dualism in abstract terms, Sidgwick as one might expect comes down on the cosmopolitan side. But when he is dealing with specific issues, such as war, or territorial disputes, or immigration, he invariably appeals to the force of patriotic feelings and commitments and addresses the issue from the national perspective, subject only to the rider that states should not actively inflict unnecessary harm on outsiders. ${ }^{18}$ The cosmopolitan ideal, he thinks, might be 'the ideal of the future' but it would be foolish to try to act on it here and now. For:

It allows too little for the national and patriotic sentiments which have in any case to be reckoned with as an actually powerful political force, and which appear to be at present indispensable to social wellbeing. We cannot yet hope to substitute for these sentiments, in

\footnotetext{
${ }^{18}$ In the case of war, a slight shift occurs in his essay 'The Morality of Strife', first delivered as an address to the London Ethical Society in 1890, where Sidgwick urges 'the thoughtful and moral part of every community', without renouncing their patriotism, to try to judge international conflicts from an impartial point of view, so that resort to war can be avoided. See Henry Sidgwick, Practical
} Ethics: A Collection of Essays and Addresses, $2^{\text {nd }}$ ed. (London: Swann Sonnenschein, 1909), pp. 105108. 
sufficient diffusion and intensity, the wider sentiment connected with the conception of our common humanity. ${ }^{19}$

This raises a general issue about the practical application of utilitarian principles. How should a utilitarian respond when confronted with anti-utilitarian beliefs and preferences, that is to say beliefs and preferences which when acted on are less conducive to the general happiness than some alternative beliefs and preferences that the agents in question could feasibly adopt? Should the utilitarian aim to change these beliefs and preferences, say by persuasion or education, or should she decide to accommodate them by designing institutions that produce optimal outcomes when people comply with them, given the beliefs and preferences that they currently have? Two factors are obviously relevant here. One is simply the extent to which the beliefs and preferences in question are actually modifiable by morally acceptable means, or on the other hand deeply embedded in people's psyche. The other is the extent to which they support valuable conventions that co-ordinate people's behaviour, where there is a risk that if the conventions collapse no better alternative will emerge in their stead. It's this second factor that presumably explains Sidgwick's verdict on the jury system. He evidently thinks it important that everyone should share a commitment to a particular institution for administering criminal justice, so if in a particular society the jury system has this standing, that argues strongly in favour of retaining it, even if a betterperforming institution could be envisaged. Reading Sidgwick, it becomes clear that both of these factors play a large role in shaping the application of his utilitarianism. Indeed they may play an even larger role in his political philosophy than in his ethics, given how far promoting the general happiness depends on people's ability to co-ordinate their behaviour on a large scale. Sidgwick plainly believes that partiality towards oneself, one's family, one's nation and so forth is deeprooted, and he also believes that the disappointment of legitimate expectations arising from these

${ }^{19}$ Elements, p. 308. 
relationships is a major source of unhappiness that cannot be ignored. These, then, are general reasons why his utilitarianism will tend to produce conservative conclusions when applied to existing practice..$^{20}$

\section{The Legitimacy of the State}

I turn next to a peculiarity in the way that Sidgwick chose to structure his political philosophy. The arrangement of material in Elements is, on closer inspection, rather odd. It divides roughly into three parts. ${ }^{21}$ The first part deals with the domestic functions of government - what the state is there to do, so to speak. In this section Sidgwick explores questions of political economy and asks how far the state should engage in what he calls 'socialistic interference', which covers pretty much anything that goes beyond preventing individuals from interfering with each other - so for example the provision of public goods is included under this heading. The second part considers the relationship between states, asking, for example, how states can justify their claims to control territory, what obligations of non-interference they owe to other states, what restraints must observed in war, and so forth. The third part discusses the institutions of government and how they

${ }^{20}$ On the conservative, almost Burkean, character of Sidgwick's utilitarianism, see also Stefan Collini, The Ordinary Experience of Civilized Life: Sidgwick's Politics and the Method of Reflective Analysis, in Essays on Henry Sidgwick, ed. by Bart Schultz (Cambridge, 1992), pp. 333-67, at pp. 349-52.

Sidgwickian ethics is, of course, also largely conservative: the substance of 'common sense morality' emerges largely intact from Sidgwick's forensic examination. But I will argue that the problems this causes for his political philosophy are much more severe.

${ }^{21}$ Formally it is divided into two parts, but my suggestion is that it is more illuminating to regard chapters $14-18$ of Part I as separated from the chapters that precede them in terms of subject matter. 
should interact, including for example the question whether the legislative body should be democratically elected (Sidgwick leans in the direction of a positive answer, although with many qualifications and specific exclusions).

I describe this arrangement as odd because it prevents Sidgwick from ever having to confront, headon, what one might think is the central question of political philosophy, namely under what conditions, if any, is a state legitimate? When we call a state legitimate, we mean that it has the right to impose its coercive authority on the people who inhabit the territory over which it exercises its jurisdiction. So a legitimacy claim has two parts to it: it has to be vindicated towards the people over whom coercive authority is exercised, and towards the territory where that authority is deployed. We need to be offered some account, such as Hobbes, for instance, gives us in the case of the people, as to how such a right can be acquired. But Sidgwick nowhere attempts to provide one. Now Sidgwick, if pressed on this point, might have tried to respond in one of two ways. He might have said that although he does not talk explicitly about legitimacy, the account he gives of the functions of government in the first part of the Elements is also implicitly an account of state legitimacy. That is, any state that discharges those functions with a sufficient degree of success protects its subject from attack, defends their property, provides various public goods, and forth - is ipso facto legitimate. It gains the right to rule merely by ruling effectively. Or he might have tried to dispense with legitimacy claims altogether (in line with his general antipathy to all talk of moral rights), and said simply that a state is justified in continuing to rule when it has shown that it is capable of ruling effectively. The substantive argument is the same in both cases, but in the first case a claim about legitimacy rides piggyback on a claim about justification: to say that a state is legitimate just is to say that the consequences of its ruling are sufficiently good. ${ }^{22}$ 
There is no doubt that Sidgwick's general approach to the legitimacy/justification issue does take the form I have suggested. For example, when discussing the issue of territory he asserts that 'the main justification for the appropriation of territory to governments is that the prevention of mutual mischief among the human beings using it cannot otherwise be adequately secured' ${ }^{23}$ This of course only provides a general justification, and does not determine which government should control which portion of territory. Sidgwick's assumption is that this is decided in practice by the contingencies of history, and that any government exercising what he calls 'a tolerably effective and continuous governmental control over the territory in question' is entitled to continue doing so. ${ }^{24}$ But the problem is whether this can be squared with his utilitarianism. For, on the one hand, if effective control of territory is what gives the state the right to exercise authority there, then why not assign territory to whichever state can do this most effectively? If state $A$ annexes the territory previously controlled by state B and then governs it more adequately than B had done, shouldn't B's title then promptly lapse in favour of A's? On the other hand, the ability to exercise control might depend on the attitudes and behaviour of the people who inhabit the territory, and they may have opinions about which state is entitled to govern them of a non-utilitarian kind (for example they may be loyal to a particular dynasty, or want to be governed only by people whose national identity they share). Perhaps, therefore, the inhabitants of B's territory will only recognize state B as legitimate,

\footnotetext{
${ }^{22}$ For the distinction between justification and legitimacy, see especially A.J. Simmons, Justification and Legitimacy, in A. J Simmons, Justification and Legitimacy: Essays on Rights and Obligations (Cambridge: Cambridge University Press, 2001).
}

${ }^{23}$ Elements, p. 252

${ }^{24}$ Elements, p. 254. 
and be disposed to resist the authority of A even though, apart from that resistance, A would do a better job of governing them. As we have seen, Sidgwick is not disposed to set such opinions aside when applying the general happiness principle to political questions. So it seems he is reduced to saying that a state's capacity to maintain social order is a necessary condition of its being legitimate and/or justified, while conceding that whether a candidate state can as a matter of fact maintain social order may depend not only on the capacities of the institution itself, but also on the political beliefs of the people it intends to govern, which may themselves take a non-utilitarian form. This then creates a dilemma for Sidgwick whenever an otherwise well-functioning state faces a challenge to its legitimacy, whether from secessionists wanting to redraw its borders to create a state of their own, or from political radicals demanding regime change. The current state would be legitimate, according to Sidgwick, if its citizens believed it to be so; but many of them do not. So what is Sidgwick to recommend? Should the beliefs of the dissidents be challenged, or instead accommodated through institutional change?

\section{Secession and Colonialism}

Although, as I have suggested, the structure of the Elements, with the discussion of the general functions of government coming before the analysis of territorial rights, allows Sidgwick to avoid confronting the legitimacy problem directly, he does address it in a more roundabout way when discussing the issues of secession and colonisation. For in this context legitimacy questions seem inescapable. Under what circumstances can a sub-group within an existing state claim the right to secede and establish a state of their own? And under what conditions can a colonial state claim the right to govern what Sidgwick would call an 'uncivilised' people? Faced with these questions, Sidgwick, as one might expect, tries to do justice to both sides of the argument. In the case of secession, he begins with what he takes to be the established view, namely that the fact that 'the interests of the seceders would be promoted or their sentiments of nationality gratified' is not enough by itself to justify secession unless there has also been 'some serious oppression or 
misgovernment of the seceders by the rest of the community'. ${ }^{25}$ So this is what today would be called a remedial-rights only theory of secession. ${ }^{26}$ But Sidgwick is not content to leave matters there, because he goes on to list the various harms and inconveniences that secession might cause to the remainder state. And then, to cap things off, he claims that a powerful reason to resist the break-up is 'the dislike of the community from which secession is proposed to lose territory that has once belonged to it, and to which it has a claim recognized by foreigners' ${ }^{27}$ This is followed by several remarks about the place that its territory holds in a country's national imagination. So although he concludes in neutral vein that 'I think it premature here to attempt a final solution of the problem presented by the conflicts of sentiments and interests which I have indicated' the reader can be left in no doubt that his position is heavily biased in favour of the pre-secession status quo.

Sidgwick, notoriously, took the Liberal Unionist position on the question of Home Rule for Ireland, so his hostility towards secession is not altogether surprising, but what may still surprise us, once again, is the readiness with which his utilitarianism accommodates sentiments and beliefs that seem detrimental in themselves to the general happiness. Why, we might ask, should people's beliefs or feelings about how far the borders of their country should extend count at all, if they do not already have a legitimate claim over the territory in question? Although a utilitarian may reasonably give weight to 'legitimate expectations', as Sidgwick often does, when it can be shown that people will suffer material loss if they are prevented from receiving what they have come to expect, it is much

\footnotetext{
${ }^{25}$ Elements, p. 226.
}

${ }^{26}$ For this terminology, see Allen Buchanan, Justice, Legitimacy, and Self-Determination (Oxford: Oxford University Press, 2004), ch. 8.

${ }^{27}$ Elements, p. 228. 
less clear that she should accommodate a purely emotional attachment to territory as justification for the state's holding on to it. For there is an obvious alternative: try to convince people to alter their views about the rightful ownership of the territory by appealing to the interests of those who presently suffer from the application of those views, by being denied their claim to selfdetermination.

A similar surprise awaits us when we turn to Sidgwick's discussion of colonialism, which is dominated by an enquiry into the cost-benefit calculus for the colonising nation of different forms of colonial rule - though interspersed with remarks about how the 'aborigines' may be treated that are guaranteed to make a modern reader wince. ${ }^{28}$ Where colonialism takes the form of a civilised nation occupying and governing a territory inhabited by uncivilised natives - I am using Sidgwick's terms here - he concedes that the immediate interests of the colonised may be put at risk, but argues that this can be outweighed by the benefits of civilisation that colonial rule may bring, itemised as 'completer internal peace and order, improved industry, enlarged opportunities for learning a better religion and a truer science' ${ }^{29}$ So this is a familiar paternalistic justification for colonialism, but the surprise lies elsewhere, in the weight that Sidgwick allows to the sentiments of the citizens of the colonizing nation:

${ }^{28}$ On the question whether Sidgwick was a racist, see Bart Schultz, Sidgwick's Racism, in Utilitarianism and Empire, ed. by Bart Schultz and Georgios Varouxakis (Lanham, MD: Lexington Books, 2005), pp 208-46; on his complex views about colonialism, see Schultz, Henry Sidgwick, ch. 7, where race issues are also discussed.

${ }^{29}$ Elements, p. 310. 
....the justifiable pride which the cultivated members of a civilised community feel in the beneficent exercise of dominion, and in the performance by their nation of the noble task of spreading the highest kind of civilisation; and a more intense though less elevated satisfaction - inseparable from patriotic sentiment - in the spread of the special type of civilisation distinctive of their nation, communicated through its language and literature.... ${ }^{30}$

The question again is whether satisfactions of this kind should be allowed to count if we are asking whether the exercise of colonial domination can be justified. Could people not be persuaded to take national pride in achievements of a different kind?

\section{Consent to Government}

There is one moment at which Sidgwick does appear to recognize that a legitimacy question arises in his treatment of colonialism. He tentatively suggests that colonial government might require the general consent of the aborigines, which might be 'presumed from agreements formally made by their chiefs', though he immediately goes on to list circumstances in which such consent is not necessary, such as 'when the civilised State has been victorious in a war provoked by the aggression of the inferior race'. ${ }^{31}$ This invites the question what weight, if any, Sidgwick attaches to consent as a source of legitimacy, bearing in mind the role it has often played in liberal theories of the state. ${ }^{32}$

${ }^{30}$ Elements, p. 312.

${ }^{31}$ Elements, pp. 323-4.

${ }^{32}$ The most celebrated of such theories is, of course, Locke's, and it is more than a little frustrating that when Sidgwick discusses Locke's political theory in The Development of European Polity, he refrains from offering any critical assessment of Locke's account of consent to government. See Henry Sidgwick, The Development of European Polity (London: Macmillan, 1903), chs. 24-25. 
This question is not easy to answer. Sidgwick appears to waver between the view that consent matters only because the need to procure it tends to align the actions of government with the general welfare of the citizen body, also serving thereby to discourage popular resistance, and the view that it has independent normative significance. Thus he supports appointing legislators by popular vote on the grounds that people are more likely to obey laws when they are given a choice about who makes them. But he qualifies this by saying that he does not endorse popular election 'on the ground of any supposed "natural right" of each individual to refuse submission to laws to which he has not "consented personally or through his representatives"'. ${ }^{33}$ This suggests that for Sidgwick the role of consent is strictly instrumental. But returning to the matter later in the Elements, he claims to accept 'as a fundamental principle of democracy' that 'government should rest on the active consent of the governed'. He explains that this need not mean 'all of the governed', and he goes on in characteristic Sidgwickian fashion to limit the scope of the principle. Nevertheless he is clearly troubled by the possibility of a substantial minority that refuses to accept the legitimacy of the regime that governs them. He denies that there exists 'any indisputable right of a numerical majority of persons inhabiting any part of the earth's surface to be obeyed by the minority who live within the same district' ${ }^{34}$ And so, in the very last pages of Elements he returns once more to secession and the conditions under which it can be justified, though again without reaching any very clear-cut conclusion. It is important to see clearly, he tells us

....that a form of government which shall enable every one to "obey himself alone" is chimerical. The coercion, by physical force in the last resort, of well-intentioned adults, is an evil which we cannot hope to eliminate by any constitutional reforms; though to diminish it

${ }^{33}$ Elements, p. 377.

${ }^{34}$ Elements, p. 648. 
without sacrificing other benefits is doubtless among the most legitimate and important aims which constitutional reformers can propose to themselves. ${ }^{35}$

These are the closing words of the book. It appears to have taken Sidgwick 650 pages to bring into clear focus what many people would regard as the central problem of political philosophy, namely how the state can be justified in coercing individuals who have not previously consented to be coerced. But a more charitable reading is that Sidgwick is throughout struggling with a rather different issue that unavoidably confronts anyone wishing to be both a liberal and a utilitarian, namely how is it possible to reconcile a robust defence of individual freedom with a utilitarian endorsement of any government that can demonstrate it is using its coercive powers to promote the general happiness?

Perhaps this conflict might have been softened had Sidgwick been willing to recognize some principle that sets unconditional limits to the exercise of these powers, for that would at least guarantee a vulnerable minority some protection from the will or the interests of the majority. But he shows no inclination to do so. He follows Bentham to the letter in repudiating any theory of prepolitical natural or human rights. He is equally critical of a principle that he attributes to both Kant and Spencer, namely that 'the coercive action of Government should aim simply at securing equal freedom to all' ${ }^{36}$ Sidgwick's general line of attack on this principle involves arguing, on the one hand, that much of what government does to protect individuals cannot be understood as

${ }^{35}$ Elements, p. 650.

${ }^{36}$ Henry Sidgwick, 'Economic Socialism' in Henry Sidgwick, Miscellaneous Essays and Addresses (London: Macmillan, 1904), p. 211. The principle is also discussed critically in Methods, pp. 274-78 and in Elements, ch. 4. 
protecting their freedom: for example, it safeguards them against various kinds of harm and nuisance that cannot be represented as constraints on their freedom, such as being subject to libellous defamation. On the other hand, an appeal to equal freedom does not, he claims, deliver the robust property rights that individualists seeks to defend, citing here Spencer's admission in his earlier work that private property in land was inconsistent with equal freedom, since unless land is abundant any one person's permanent appropriation of the soil risks denying others a similar opportunity to appropriate. ${ }^{37}$ Sidgwick's conclusion, predictably, is that although there must be a general presumption against government's interfering with individual liberty, there are no fixed criteria for deciding which interventions are permissible and which are not. Only an appeal to the general happiness can provide coherent guidance.

\section{Moralism and Realism in Political Philosophy}

I have argued that although Sidgwick has much to say about the functions of government, both internal and external, he never squarely faces the legitimacy question. Can this help us solve the initial puzzle, namely why his political philosophy has suffered from extreme neglect while his moral philosophy continues to be widely studied and admired? It may be helpful here to look at Sidgwick from a perspective that Bernard Williams has introduced, namely the contrast between political moralism and political realism. ${ }^{38}$ Political moralists, according to Williams, see political theory as 'something like applied morality'. 'The theory's perspective on society is that of surveying it to see

\footnotetext{
${ }^{37}$ Sidgwick, Economic Socialism, pp. 211-212. The reference is to Herbert Spencer, Social Statics (London: Chapman, 1851).
}

${ }^{38}$ For a slightly different way of positioning Sidgwick's political philosophy within this framework, see David Runciman, What is Realistic Political Philosophy?, Metaphilosophy 43 (2012), 58-70. 
how it may be made better', he says. ${ }^{39}$ For political realists, on the other hand, the problem of political legitimacy comes before all else, and solving it depends on finding a justification for the exercise of coercive power that is acceptable to almost all those who are subjected to it. Williams claims that this must involve an appeal to distinctively political values, since there is no reason to believe that general moral values can perform this justificatory role.

Williams presents utilitarian political philosophies as prime examples of political moralism, and it looks very much as though Sidgwick fits the bill. As we have seen, he assumes without the need for further argument that the same normative standard - the general happiness principle - should be applied to political issues as to individual conduct. The independent justification he offers for that principle, such as it is, is presented entirely in Book III, ch. 13 of the Methods. It does not occur to him to ask whether politics might have features that demand that a different standard of evaluation should be applied in that domain. Another way to bring the point out is to ask who Sidgwick thought he was writing for when he sat down to compose the Elements. The answer, plainly, is the established political class - politicians, administrators, colonial governors. These are the thoughtful persons whose opinions he represents and whose practical problems he tries to address. ${ }^{40}$ How far should government try to intervene in the workings of a market economy? Which classes of persons ought to be given the vote? How should distant colonies best be governed? And so on. To these

${ }^{39}$ Bernard Williams, Realism and Moralism in Political Theory, in Bernard Williams, In the Beginning was the Deed: Realism and Moralism in Political Argument, ed. by Geoffrey Hawthorn (Princeton, NJ: Princeton University Press, 2005), pp. 1-2.

${ }^{40}$ For further reflection on this point, see Collini, The Ordinary Experience of Civilized Life, pp. 358-

61. Collini cites Sidgwick's remark that his aim in Elements was 'to treat systematically the chief questions for which the statesman has to find answers' (italics added). 
questions he gives broadly utilitarian answers, but, as we have seen, answers that are heavily conditioned by existing expectations, preferences and attitudes. So as a political moralist, he is bound to disappoint those whose aim is, as Williams puts it, to survey society to see how it could be made better, a process that is likely to involve criticising and challenging these psychological dispositions. Later utilitarians sympathetic to Sidgwick seem to have avoided embarrassment by turning a blind eye to Sidgwick's political philosophy. Peter Singer, for example, makes no mention of it at all in his recent co-authored presentation and defence of Sidgwickian ethics. ${ }^{41}$ When on an earlier occasion he had referred to the Elements in passing, he cited Sidgwick's adoption of the general happiness as the standard by which political arrangements are to be judged, but neglected to point out that Sidgwick addresses almost all practical questions of policy from the national rather than the cosmopolitan perspective. ${ }^{42}$ The general happiness that matters for political purposes is almost exclusively the happiness of compatriots, not of foreigners.

Shunned by political moralists, might Sidgwick's political thought appeal to realists, even though he fails to qualify for that label according to the Williams test? In a looser sense, there is much about Sidgwick's thought that we might describe as realistic, such as his extreme caution about reformist proposals whose outcome cannot be predicted with any confidence, and his assumption that in international relations states will inevitably pursue their national interests at the expense of

\footnotetext{
${ }^{41}$ Katarzyna de Lazari-Radek and Peter Singer, The Point of View of the Universe: Sidgwick and
} Contemporary Ethics (Oxford: Oxford University Press, 2014).

${ }^{42}$ Peter and Renata Singer, The Ethics of Refugee Policy, in Population and Political Theory: Philosophy, Politics and Society 8, ed. by James Fishkin and Robert Goodin (Chichester: WileyBlacwell, 2010), p. 296. 
cosmopolitan ideals. ${ }^{43}$ But realists are bound to see Sidgwick as too complacent about political order. He seems unable or unwilling to recognize what we might call 'the darker face of realism'. This is the conviction, certainly present in Williams, that politics is always a somewhat fragile device for resolving differences of interest and belief that would otherwise erupt in the form of violent conflict. Sidgwick assumes right from the beginning of Elements that his topic is the government of 'civilised societies' whose members habitually conform to the State's commands. ${ }^{44}$ The only moments at which he displays any anxiety that civilisation so understood might be vulnerable to popular resistance are those in which he is discussing the significance of democratic consent. Here there is glimmer of recognition that political power finally lies in the hands of the masses, and that if they are not given sufficient inducements to comply with the state, they might decide to exercise their latent power in revolutionary fashion. ${ }^{45}$ But the way that Sidgwick poses the question is always as 'how can the problem best be managed?' rather than 'what makes the state's coercion of unwilling subjects legitimate?' Here is his answer:

${ }^{43}$ In his essay on 'Public Morality', Sidgwick argues that although public morality - the morality of statesmen - is not categorically different from private morality, nevertheless the circumstances of international politics mean that states are entitled to pursue their national interests by quite ruthless means unless they can be assured that other states will reciprocate their self-restraint. See Henry Sidgwick, National and International Right and Wrong: Two Essays (London: Allen and Unwin, 1919).

${ }^{44}$ See Elements, pp. 1-5.

${ }^{45}$ Elements, ch. 31. 
I think it important to dispel the illusion that any form of government can ever give a complete security against civil war. Such a security, if attained, must rest on a moral rather than political basis; it must be maintained by the moderation and justice, the comprehensive sympathies and enlightened public spirit of the better citizens, keeping within bounds the fanaticism of sects, the cupidities of classes, and the violence of victorious partisanship. ${ }^{46}$

I believe we are now in a position to understand the deep neglect into which Sidgwick has fallen as a political philosopher. Those who continue to work within the utilitarian tradition of moral and political philosophy are nearly all progressives. As moral philosophers they urge us to extend our benevolence far beyond the limits that ordinary morality demands; as political philosophers they are likely to be cosmopolitan would-be reformers of prevailing national and international institutions. ${ }^{47}$ So they are happy to take from Sidgwick the idea that utilitarianism can capture all that is worth capturing in common sense morality, while turning their backs on Sidgwick's applications of that doctrine to politics. For political realists, on the other hand, who might agree with some of Sidgwick's practical conclusions, his manner of reaching them will always sound far too complacent. Sidgwick's general message, faced with possible threats to the established order, is roughly 'all will be well so long as there are sensible chaps like me in charge ('the enlightened public spirit of the better citizens')'. Neither side, then, has reason to look for inspiration to Sidgwick's political philosophy.

\section{Conclusion: Sidgwick and Reflective Equilibrium}

${ }^{46}$ Elements, p. 648.

${ }^{47}$ Both of these characteristics are exemplified in texts such as Peter Singer's One World: The Ethics of Globalization (New Haven and London: Yale University Press, 2002). 
Besides the satisfaction of having solved the original puzzle, is there anything more we can take away from this probing of Sidgwick's political thought? There may be a methodological lesson to be learned. Sidgwick is justly admired as the originator of the justificatory strategy that has come to be called, following Rawls, reflective equilibrium. ${ }^{48}$ Moral and political theories are to be tested in part by their ability to capture the intuitive judgements that we feel most confident about, insofar as they can be reconciled with general principles we are inclined to adopt. But it seems that in political philosophy we must be far more circumspect in appealing to our own judgements on political questions, especially when we have reason to think that they reflect the opinions of the narrow social circle to which we happen to belong. When Sidgwick examines 'common sense morality', he assumes that there will be agreement on its contents 'at least among moral persons of our own age and civilisation', but he immediately goes on to qualify that by limiting the relevant group to 'that portion of mankind which combines intellectual enlightenment with a serious concern for morality'. ${ }^{49}$ There is no hint that this might be a socially exclusive constituency. Perhaps in most areas of moral philosophy the damage wrought by relying on the opinions of this group is not so great. But in political philosophy it is certainly damaging if the aim is to arrive at an inclusive and not merely sectional form of reflective equilibrium. Take the question of the extension of the franchise, a live political topic at the time Sidgwick was writing, and especially the issue of women's suffrage.

${ }^{48}$ There is some disagreement about the exact relationship between Sidgwick's methodology and Rawls's, but what is not in question is that Rawls at least took himself to be following in Sidgwick's footsteps when he expounded the method of reflective equilibrium. For contrasting views, see Peter Singer, Sidgwick and Reflective Equilibrium, The Monist 58 (1974), 490-517, and Steven Sverdlik, Sidgwick's Methodology, Journal of the History of Philosophy 23 (1985), 537-53.

${ }^{49}$ Methods, p. 215. 
Sidgwick gives considerable weight to various arguments In favour of restricting the franchise that were popular in the circles he moved in. ${ }^{50}$ For instance, he confidently asserts that there is no strong case for granting votes to married women since 'it may be plausibly urged that the political interests of wives, daughters, and sisters are safe in the hands of husbands, fathers, and brothers' ${ }^{51}$ He also takes quite seriously the so-called 'physical force' argument against women's suffrage in general, which holds that 'the franchise belongs as a right to those who will defend their country when attacked', even though he argues that it less applicable in contemporary circumstances when military service is usually performed on a voluntary basis. ${ }^{52}$ In contrast, the simple idea that, absent specific disqualifying conditions such as insanity, all citizens have an equal right to vote is never contemplated, presumably because it found no place in the argumentative arsenal of the political circles in which Sidgwick moved. (Sidgwick's own preference was for a franchise weighted in favour of the educated classes, though he recognized the difficulties that implementing it would pose).

In short, the problem with Sidgwick's political philosophy is not that the conclusions he reaches are largely conservative. The problem has to do with the way he reaches them: through paying scrupulous attention to the opinions and arguments currently favoured in the social and political circles in which he moved, on the assumption that these must be capable of being recast in utilitarian form. So beyond the general difficulty that critics detect when what appear to be non-

\footnotetext{
${ }^{50}$ Sidgwick's timidity in relation to women's suffrage, and its source in his reliance on 'common sense' precepts, is noticed in Ross Harrison, Henry Sidgwick, Philosophy 71 (1996), 423-38.
}

${ }^{51}$ Elements, p. 379.

${ }^{52}$ Elements, pp. 385-6. For the provenance of this argument, see Brian Harrison, Separate Spheres: The Opposition to Women's Suffrage in Britain (London: Croom Helm, 1978), ch. 4. 
consequentialist principles are reconstructed along utilitarian lines, we have the specific problem that at least part of the raw argumentative material that Sidgwick is working with might simply be class- or gender-biased, and therefore not even notionally aimed at promoting the good of all. So progressive utilitarians will turn away from Sidgwick's political philosophy, regarding it as superannuated, without noticing that this failing stems directly from the application of a methodology that elsewhere - in his ethics - they celebrate. ${ }^{53}$ Realists who might share his conservative conclusions, by contrast, are likely to fault Sidgwick for sidestepping what they see as the fundamental problem of politics - namely how political order can be created in the first place, in a world prone to violence - by assuming that the question to be discussed is how best to constitute and govern a modern state whose subjects are already generally inclined to comply with its commands. For want of friends on either side of this divide, his political philosophy has understandably fallen into oblivion. ${ }^{54}$

${ }^{53}$ Thus Singer is happy to reverse many of the practical conclusions that Sidgwick reaches - for example, his endorsement of various forms of partiality, towards kinsmen, compatriots, etc. - while continuing to treat Methods as the supreme statement of utilitarian philosophy: compare Singer, One World, ch. 5 with the Preface to Lazari-Radek and Singer, The Point of View of the Universe. This can only be done by disregarding Sidgwick's own conception of his method.

${ }^{54}$ This article originated in a lecture given to the Philosophy Faculty, Cambridge University on $24^{\text {th }}$ May, 2017. I am very grateful to members of the audience for questions raised at that event, and to Tom Hurka and two anonymous referees for this Journal for their comments on a later version. 